\title{
A test of the sponge-loop hypothesis for emergent Caribbean reef sponges
}

\author{
Steven E. McMurray ${ }^{1, *}$, Amber D. Stubler ${ }^{1,2}$, Patrick M. Erwin', \\ Christopher M. Finelli ${ }^{1}$, Joseph R. Pawlik ${ }^{1}$ \\ ${ }^{1}$ Department of Biology and Marine Biology, University of North Carolina Wilmington, Wilmington, North Carolina, USA \\ ${ }^{2}$ Biology Department, Occidental College, 1600 Campus Road, Los Angeles, California, USA
}

ABSTRACT: The sponge-loop hypothesis proposes that coral reef sponges convert the dissolved organic matter (DOM) released by benthic primary producers into particulate detritus available to higher trophic levels. The hypothesis was developed and subsequently supported from studies of cryptic, encrusting sponges; however, the sponge-loop has yet to be considered for massive, emergent sponge species that dominate the surface of Caribbean reefs and represent a large proportion of sponge community biomass. We tested the generality of the sponge-loop for emergent sponge fauna by using direct In-Ex methods combined with acoustic Doppler velocimetry and sponge volume calculations to quantify carbon flux for 9 sponge species representing a variety of functional types. The diet of 5 species hosting abundant symbiotic microbes (HMA) primarily consisted of dissolved organic carbon (DOC), while 4 species with low microbial abundances (LMA) primarily consumed detritus and picoplankton. None of the sponge species studied were found to produce significant quantities of detritus. We conclude that, instead of releasing assimilated carbon in the form of detritus, as originally proposed by the sponge-loop for encrusting, cryptic sponges, emergent sponge species likely retain assimilated carbon as biomass. Given the high rates of DOC uptake observed for HMA species, we propose an additional pathway by which the sponge-loop fuels higher trophic levels via predation by fish, turtle, and invertebrate spongivores.

KEY WORDS: Benthic-pelagic coupling $\cdot$ Suspension feeding $\cdot$ Dissolved organic carbon $\cdot$ DOC $\cdot$ Particulate organic carbon $\cdot \mathrm{POC} \cdot$ Porifera $\cdot$ Detritus

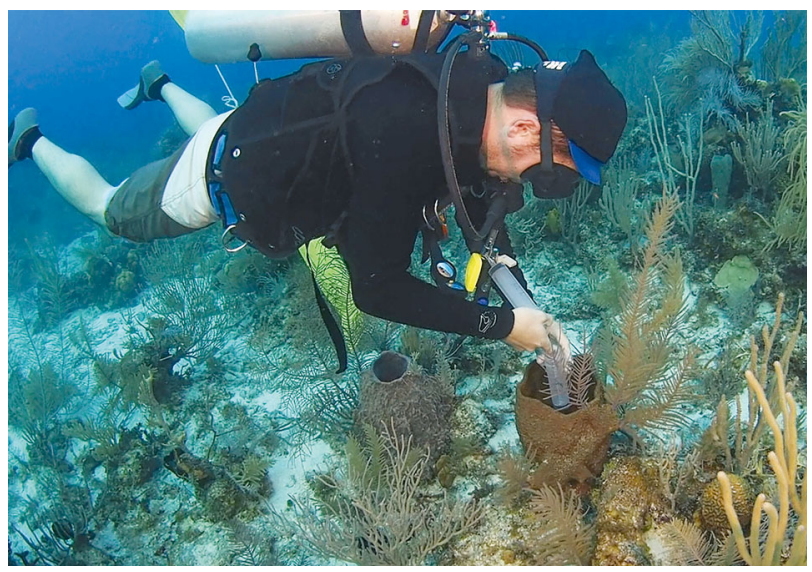

Analyses of seawater collected before and after passage through emergent sponge species reveal that they are not net producers of detritus.

Photo: Joseph R. Pawlik

\section{INTRODUCTION}

The microbial loop (Azam et al. 1983) transformed our understanding of trophic interactions in the ocean and finally unraveled the paradox of abundant planktonic life in the oligotrophic open ocean (Pomeroy et al. 2007). It is now understood that the structure of plankton communities is a web of trophic interactions, rather than a simple linear chain, largely driven by the cycling of carbon and nutrients by microbes (Fenchel 2008). By consuming the dissolved organic matter (DOM) released by phytoplankton that would otherwise be lost to the environ-

() The authors 2018. Open Access under Creative Commons by Attribution Licence. Use, distribution and reproduction are unrestricted. Authors and original publication must be credited. 
ment, microbes remineralize nutrients that fuel primary production and return assimilated DOM to the planktonic food web via protists (Fenchel 2008).

More recently, a process analogous to the microbial loop has been hypothesized to explain a similar paradox: how highly productive and diverse coral reef ecosystems occur in desert-like tropical seas. Specifically, it was proposed that sponges, and their symbiotic microbes, may sustain the high productivity of coral reef ecosystems by mediating the recycling of primary production released by reef-building corals and macroalgae in the form of DOM (de Goeij et al. 2013). Through this process, termed the 'sponge-loop', sponges consume dissolved organic carbon (DOC), and up to $40 \%$ of this carbon is subsequently released as particulate organic carbon (POC) in the form of shed cellular detritus that is then assimilated by benthic detritivores and suspension feeders and subsequently passed to higher trophic levels via predation (de Goeij et al. 2013, Rix et al. 2016, 2017). Although the underlying mechanism of detritus production in the spongeloop has yet to be resolved, it is hypothesized that there is a trade-off between sponge growth and detritus production, with the latter linked to rapid cell turnover, primarily of choanocytes, through cell proliferation and cell shedding (de Goeij et al. 2009, 2013, Alexander et al. 2014, 2015; but see Kahn \& Leys 2016).

Like the microbial loop, the sponge-loop has the potential to explain an important link in the cycling of carbon in coral reef ecosystems. There is good evidence that primary producers on coral reefs (seaweeds and corals) release up to $50 \%$ of their fixed carbon as mucus and other exudates, and that most of these exudates become part of the DOC pool (Wild et al. 2004, Haas et al. 2010). Further, sponges have the capacity to turn over huge quantities of seawater in the process of feeding. Reiswig (1974) estimated that the sponge community of Discovery Bay, Jamai-

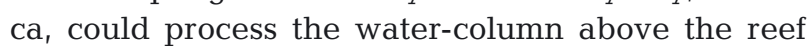
each day to a depth of 15.5 to $40.0 \mathrm{~m}$; more recently, work with the giant barrel sponge Xestospongia muta from the Florida Keys and Bahamas indicates that this species alone can overturn a volume of water equivalent to a layer of 1.7 to $12.9 \mathrm{~m}$ each day (McMurray et al. 2014). Therefore, the sponge-loop could be a dominant and previously unrealized component in the cycling of carbon for coral reef ecosystems. Indeed, it has already been invoked to explain phase shifts in fish biomass on impacted reefs (Silveira et al. 2015). Moreover, DOM consumption by sponges may contribute to a reciprocal positive interaction with macroalgae, whereby remineralized nutrients fuel the growth of macroalgae that subse- quently results in enhanced levels of macroalgalderived DOM; a process termed the 'vicious circle hypothesis' because of the detrimental effect that enhanced sponge and macroalgal growth has on the ability of reef-building corals to compete for space in benthic reef communities (Pawlik et al. 2016).

As originally developed, the sponge-loop hypothesis was based on studies of 4 species of cryptic, encrusting Caribbean sponge species using augmented DOC in the form of laboratory-produced diatom extract (de Goeij et al. 2013). Notably, an increasing number of sponge species have been found to feed on DOC (Yahel et al. 2003, de Goeij et al. 2008b, Ribes et al. 2012, Mueller et al. 2014, McMurray et al. 2016, 2017, Archer et al. 2017, Hoer et al. 2018, Morganti et al. 2017), and a link between DOC uptake and detritus production has been established for additional cryptic sponge species (Alexander et al. 2014, Rix et al. 2016, 2017). While it was generally thought that sponge species with dense assemblages of symbiotic microbes - i.e. high microbial abundance (HMA) sponges (Gloeckner et al. 2014) derive a majority of their dietary carbon from DOC, and low microbial abundance (LMA) sponges derive it from filtering POC (Maldonado et al. 2012, Hoer et al. 2018), there is increasing evidence that some LMA sponges consume DOC (Mueller et al. 2014, Rix et al. 2016, 2017, Morganti et al. 2017) and that sponge cells are directly involved in DOC uptake (de Goeij et al. 2008a, Rix et al. 2016, 2017). The spongeloop has been supported in recent studies of encrusting species using more ecologically-relevant DOC types, including coral- and algal-derived DOC (Rix et al. 2017), and assimilation rates for these DOC types are comparable to those for diatom-derived DOC (de Goeij et al. 2013). Further, the sponge-loop has been found to function for sponge species spanning a broad geographic range, including the Red Sea, temperate Mediterranean, and deep-water North Atlantic (Alexander et al. 2014, Rix et al. 2016).

Despite growing support for the sponge-loop, the ecological significance and generality of the hypothesis across the Porifera remains unclear. To date, the sponge-loop has been exclusively studied using incubation methods, both in the laboratory and in situ, with isotopically-enriched, and generally labile, DOM as a tracer to follow sponge DOM uptake and detritus production (de Goeij et al. 2013, Rix et al. 2016, 2017) and subsequent detritus transfer to higher trophic levels (de Goeij et al. 2013). However, the hypothesis has yet to be tested in situ using the natural pool of DOM found in seawater over coral reefs. The DOM pool available on coral reefs is highly heterogeneous 
(Hansell \& Carlson 2002), consisting of a mixture of refractory and labile forms that likely vary in their bioavailability to sponges (Yahel et al. 2003, de Goeij et al. 2008b). Additionally, both the quality (Rix et al. 2017) and concentration (Mueller et al. 2014, McMurray et al. 2016, 2017, Archer et al. 2017, Morganti et al. 2017) of DOC are known to affect rates of sponge-mediated DOC flux. Even more striking is that work on the sponge-loop has thus far been limited to sponge species with thinly encrusting growth forms that typically live in reef interstices. Massive and emergent sponge species, which dominate the surface of Caribbean coral reefs (Loh \& Pawlik 2014), represent a large proportion of total coral reef sponge biomass and are therefore expected to represent a substantial contribution to carbon cycling if they participate in the sponge-loop. While DOC uptake has been demonstrated for a few emergent sponge species (Yahel et al. 2003, McMurray et al. 2016, 2017, Archer et al. 2017, Hoer et al. 2018), potential detritus production has yet to be quantified for these species (but see McMurray et al. 2016).

The purpose of this study was to test the generality of the sponge-loop in situ with emergent species spanning a variety of functional types. A total of 9 sponge species were chosen for this study from a range of taxonomic groups and including both HMA and LMA sponge types; all chosen species exhibit morphologies (tube, vase, and barrel) that separate incurrent from excurrent seawater flow. In addition to differences in the abundance and diversity of microbial symbiont communities (Gloeckner et al. 2014), a number of other functional traits may influence sponge-mediated carbon flux for HMA and LMA species, with the latter having more porous tissue and higher rates of pumping activity, greater densities of choanocyte chambers, and shorter and wider water canals (Weisz et al. 2008, Poppell et al. 2014). We used direct In-Ex methods (Yahel et al. 2005) combined with acoustic Doppler velocimetry to measure sponge pumping and geometric estimates of sponge volume to quantify the natural flux of detritus from unmanipulated individual sponges. We conducted our studies at 2 locations expected to vary in the composition and concentration of particulate and dissolved food resources available to sponges.

\section{MATERIALS AND METHODS}

Carbon flux was quantified for sponges on Conch Reef, Key Largo, Florida $\left(24^{\circ} 56.9^{\prime} \mathrm{N}, 80^{\circ} 27.2^{\prime} \mathrm{W}\right)$, and reefs off Carrie Bow Cay, Belize $\left(16^{\circ} 56.9^{\prime} \mathrm{N}\right.$, $80^{\circ} 27.2^{\prime} \mathrm{W}$ ), in June and July 2016, respectively. At each location, a total of 2 to 7 individuals each of 8 large and abundant emergent sponge species, common throughout the Caribbean, were haphazardly selected for study at between 15 and $20 \mathrm{~m}$ depths. Sponge species were chosen that exhibit morphologies that distinctly separate incurrent from excurrent flow; these include barrel, vase and tube-forming species. Of the species investigated, Agelas tubulata (cf. conifera), Verongula gigantea, V. reiswigi, and Xestospongia muta are considered HMA species and Callyspongia plicifera, C. vaginalis, Mycale laxissima, and Niphates digitalis are considered LMA species (Weisz et al. 2008, Maldonado et al. 2012, Gloeckner et al. 2014). An additional species, the HMA sponge Ircinia strobilina, was selected for study on Conch Reef only. With the exception of $A$. tubulata, only individuals with a single osculum were studied for each species. Additionally, only sponges with no obvious signs of disease or tissue damage and not fouled with algae or colonized by epibionts (e.g. zoanthids) were included. For photographs and descriptions of each species, see Zea et al. (2014).

Paired 1.51 incurrent (ambient) and excurrent seawater samples were collected from each sponge with $100 \mathrm{ml}$ syringes ( $5 \mathrm{~mm}$ diameter tip opening) as previously described (McMurray et al. 2016) for measurements of live particulate organic carbon (LPOC), total POC, and DOC. Briefly, incurrent seawater samples were collected adjacent to the ostia lining the external sponge surface and excurrent samples were slowly collected from approximately $5 \mathrm{~cm}$ below the osculum within the atrium (inner empty space) of each sponge and at a rate lower than the excurrent water velocity to avoid contamination from ambient seawater. Samples thus represent an integration of approximately 10 to $20 \mathrm{~min}$ of sponge feeding. Following seawater collection, the velocity of excurrent seawater at the centerline of the osculum of each sponge was measured using a Sontek Micro acoustic Doppler velocimeter (ADV) mounted on a tripod for 3 min at $2 \mathrm{~Hz}$ (McMurray et al. 2014). The dimensions of each sponge were subsequently measured using a flexible measuring tape and sponge volume, excluding the spongocoel, was calculated by approximating the morphology of each individual as an appropriate geometric solid (McMurray et al. 2008).

To quantify the flux of LPOC in the form of picoplankton, $5 \mathrm{ml}$ of both incurrent and excurrent seawater samples were preserved in electron microscopy grade glutaraldehyde at a final concentration of $0.1 \%$ in cryovials for $10 \mathrm{~min}$ in the dark and subsequently frozen in liquid nitrogen and stored at $-80^{\circ} \mathrm{C}$ 
until flow cytometry analysis. Phytoplankton (Prochlorococcus [Pro], Synechococcus [Syn], and photosynthetic pico- and nanoeukaryotes [Euk]) and bacterioplankton (high nucleic acid bacteria [HNA] and low nucleic acid bacteria [LNA]) in seawater samples were enumerated using a BD FACSCelesta flow cytometer and populations were characterized as previously described (McMurray et al. 2016). Briefly, cells were excited with a $488 \mathrm{~nm}$ laser and forward scatter, side scatter, green fluorescence $(530 \pm 30 \mathrm{~nm})$, orange fluorescence $(575 \pm 26 \mathrm{~nm})$, and red fluorescence (695 \pm $40 \mathrm{~nm}$ ) emissions were measured. Phytoplankton were analyzed for $10 \mathrm{~min}$ at high flow rate and heterotrophic bacteria were stained with Sybr Green-I as previously described (Marie et al. 1997) and analyzed at low flow rate for $5 \mathrm{~min}$. Picoplankton were classified based on their characteristic flow cytometric signatures relative to standard fluorescent microspheres following standard population gating schemes (Cavender-Bares et al. 1998). Carbon content of each type of picoplankton was estimated using standard cell conversions used in previous studies of sponge feeding (e.g. Pile 1997, Lesser 2006, Morganti et al. 2017): $53 \mathrm{fg} \mathrm{C}$ cell $^{-1}$ for Pro (Morel et al. 1993), $470 \mathrm{fg}$ $\mathrm{C} \mathrm{cell}^{-1}$ for Syn (Campbell et al. 1994), $1496 \mathrm{fg} \mathrm{C} \mathrm{cell}^{-1}$ for Euk (Zubkov et al. 1998), and $20 \mathrm{fg} \mathrm{C} \mathrm{cell}^{-1}$ for HNA and LNA bacteria (Ducklow et al. 1993).

To quantify sponge-mediated flux of POC and DOC, the remaining seawater from each sample was filtered through a $100 \mu \mathrm{m}$ mesh that excluded particles greater than the size of incurrent ostia and subsequently through a precombusted GF/F glass fiber filter under low pressure. Filters were individually wrapped in aluminum foil and frozen until analysis of $\mathrm{POC}_{i} 20 \mathrm{ml}$ of the filtrate from each sample was transferred to an EPA precleaned glass vial, acidified with $100 \mu \mathrm{l}$ of $50 \%$ phosphoric acid, and stored at $4{ }^{\circ} \mathrm{C}$ until analysis of DOC. POC was measured using a CE Elantech NC2100 combustion elemental analyzer after filters were dried at $50^{\circ} \mathrm{C}$ and subsequently exposed to hydrochloric acid fumes for $24 \mathrm{~h}$. DOC was measured using high temperature catalytic oxidation with a Shimadzu TOC 5050 analyzer (McMurray et al. 2016). Calibration was achieved with standards diluted from a stock solution of potassium hydrogen phthalate and both standards and deep seawater consensus reference material (Batch 9, Lot \#09-09 from the Hansell Laboratory, Rosenstiel School of Marine and Atmospheric Science, University of Miami) were interspersed with samples for quality assurance and control. Each seawater sample was run in duplicate and each analysis tube was injected 3 to 5 times for a coefficient of variance $<1.5 \%$.
The approximate analytical precision of the instrument was $2 \mu \mathrm{mol} \mathrm{C} \mathrm{^{-1 }}$ seawater. All plastic used for sample collection was soaked in a $0.5 \mathrm{M} \mathrm{HCl}$ bath for at least $24 \mathrm{~h}$ and subsequently thoroughly rinsed in ultrapure water before use and all glassware and aluminum foil used to process samples were combusted at $450^{\circ}$ for $>4 \mathrm{~h}$ prior to use (Tupas et al. 1994). Some samples were discarded due to potential contamination while processing in the field; therefore, a small number of individuals are lacking flux estimates for 1 or 2 of the 3 carbon pools investigated (see Table 1 below in 'Results' for sample sizes).

Detrital carbon in incurrent and excurrent seawater samples was estimated as the portion of total POC not accounted for by LPOC (i.e. Detritus $=$ POC LPOC) (Ribes et al. 1999, Hadas et al. 2009, McMurray et al. 2016). Sponge specific filtration rates, or carbon flux ( $\mu \mathrm{mol} \mathrm{C} \mathrm{s}{ }^{-1} \mathrm{l}^{-1}$ sponge), of DOC, LPOC, and detritus were calculated as:

$$
C \text { flux }=\frac{\left(C_{\text {in }}-C_{\text {ex }}\right) \times Q}{V_{\text {sponge }}}
$$

where $C_{\mathrm{in}}$ and $C_{\mathrm{ex}}$ are the incurrent and excurrent concentrations of each carbon pool $\left(\mu \mathrm{mol} \mathrm{C} \mathrm{l^{-1 }}\right.$ seawater), $V_{\text {sponge }}$ is sponge tissue volume (1), and $Q$ is the volume flow or pumping rate for each sponge $\left(\mathrm{l} \mathrm{s}^{-1}\right)$. Positive and negative flux estimates therefore represent consumption and production of a particular carbon pool, respectively. For $Q$, we assumed that the mean excurrent velocity for each sponge was equivalent to the velocity of seawater measured at the osculum centerline with an ADV (i.e. plug flow), and volume flow was calculated as the product of the centerline excurrent velocity and the osculum area; for $X$. muta, the mean excurrent seawater velocity for each sponge was corrected for the uneven velocity distribution across the osculum due to the morphology of the spongocoel (Eq. 3 in McMurray et al. 2014).

For all analyses, assumptions of normality and homogeneity of variances were checked with box and residual plots and data were transformed as needed or nonparametric tests were used. $\log _{10^{-}}$ transformed incurrent carbon concentrations were compared between locations (Conch Reef and Carrie Bow Cay) and carbon pools (DOC, LPOC, detritus) with a 2-way ANOVA and significant interactions were evaluated by tests of simple main effects. Specific filtration rates were compared between locations, sponge species, and carbon pools using the Scheirer-Ray-Hare extension of the Kruskal-Wallis test (Sokal \& Rohlf 1995); V. gigantea and V. reiswigi were excluded from this analysis due to insufficient replication for these species at Carrie Bow Cay and 
Conch Reef, respectively. To test the hypothesis that sponges are net producers (or consumers) of detritus, paired $t$-tests were used to compare the concentrations of detritus in incurrent and excurrent seawater for each species. Statistical analyses were conducted with SAS version 9.1.3 for Windows (SAS Institute) and SPSS Statistics version 22 for Windows (IBM) statistical software.

\section{RESULTS}

The concentration of incurrent (ambient) carbon available to sponges over the study period significantly differed between locations $\left(F_{1,222}=48.99\right.$, $\mathrm{p}<$ $0.001)$ and between carbon pools $\left(F_{2,222}=2192.92, \mathrm{p}<\right.$ 0.001). Additionally, differences in the concentrations between carbon pools significantly varied between study locations (carbon pool by location interaction: $F_{2,222}=14.19, \mathrm{p}<0.001$; Fig. 1). Comparisons of simple main effects indicated that the concentration of incurrent carbon significantly differed between carbon pools at both Conch Reef $\left(F_{2,222}=\right.$ 1058.30, $\mathrm{p}<0.001)$ and Carrie Bow Cay $\left(F_{2,222}=\right.$ 1138.87, $\mathrm{p}<0.001$ ). Pairwise comparisons revealed that there was more carbon in the form of DOC relative to detritus and LPOC ( $p<0.001$ for both tests),

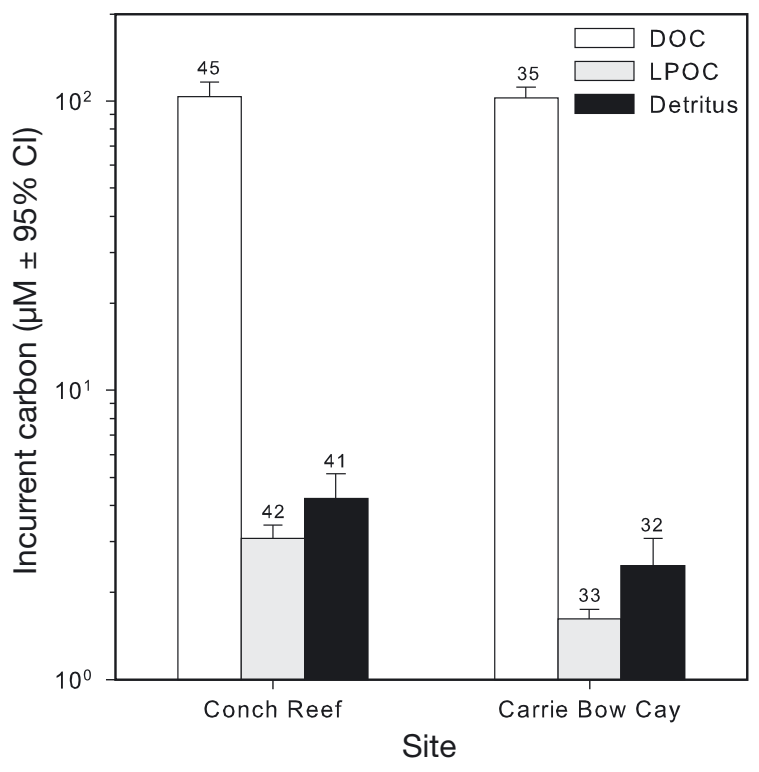

Fig. 1. Mean $( \pm 95 \% \mathrm{CI})$ concentration of dissolved organic carbon (DOC), live particulate organic carbon (LPOC), and detritus in incurrent (ambient) seawater on Conch Reef, Key Largo, FL, and Carrie Bow Cay, Belize, over the study period. Numbers above the bar represent sample sizes; these were variable because some samples were discarded due to potential contamination while processing in the field and more detritus relative to LPOC $(p=0.023)$ at Conch Reef; the same pattern held at Carrie Bow Cay, with more DOC than detritus and LPOC $(\mathrm{p}<$ $0.001)$, and more detritus than LPOC ( $p=0.006)$. The concentrations of LPOC and detrital carbon were significantly greater at Conch Reef relative to Carrie Bow Cay (LPOC: $F_{1,222}=42.80, p<0.001$; detritus: $F_{1,222}=32.03, \mathrm{p}<0.001$ ), but DOC concentrations were similar between locations $\left(F_{1,222}=0.05, \mathrm{p}=\right.$ 0.817). Mean $\pm 95 \%$ CI concentrations of ambient DOC, detritus, and LPOC were 103.4 $\pm 12.7,4.23 \pm$ 0.89 , and $3.07 \pm 0.34 \mu \mathrm{M}$ at Conch Reef and $102.7 \pm$ 8.8, $2.48 \pm 0.57$, and $1.62 \pm 0.12 \mu \mathrm{M}$ at Carrie Bow Cay, respectively (Fig. 1).

Of the 59 sponges at both locations for which detrital carbon flux was measured, 11 individuals were found to have net production of detritus (negative flux); all others had net consumption of detritus (positive flux). Detrital production for these 11 individuals was generally small, with 7 emitting $<0.009 \mu \mathrm{mol}$ detrital $\mathrm{C} \mathrm{s}^{-1} \mathrm{l}^{-1}$ sponge, 3 emitting 0.03 to $0.05 \mu \mathrm{mol}$ $\mathrm{C} \mathrm{s}^{-1} \mathrm{l}^{-1}$ sponge, and 1 emitting $0.20 \mu \mathrm{mol} \mathrm{C} \mathrm{s}{ }^{-1} \mathrm{l}^{-1}$ sponge. The 11 individuals with detrital production were spread over 7 different species. Individuals of Ircinia strobilina and Niphates digitalis only exhibited net detritus consumption (positive flux).

In terms of mean responses for the 9 species investigated at Conch Reef and the 8 species investigated at Carrie Bow Cay, only Mycale laxissima at Carrie Bow Cay was found to have mean detritus production $\left(-0.0004 \pm 0.003 \mu \mathrm{mol} \mathrm{C} \mathrm{s}{ }^{-1} \mathrm{l}^{-1}\right.$ sponge, mean \pm $95 \% \mathrm{CI}$ ), however, the concentration of detritus in excurrent seawater was not significantly different from that in ambient seawater $(t=-0.12, \mathrm{df}=4, \mathrm{p}=$ 0.91 ) and conspecifics at Conch Reef had mean consumption of detritus (Fig. 2, Table 1). Only 1 individual each of Verongula reiswigi at Conch Reef and of V. gigantea at Carrie Bow Cay were measured and both were found to have negative detrital carbon flux $\left(-0.008\right.$ and $-0.20 \mu \mathrm{mol} \mathrm{C} \mathrm{s}{ }^{-1} \mathrm{l}^{-1}$ sponge, respectively), but conspecifics of $V$. reiswigi at Carrie Bow Cay and V. gigantea at Conch Reef were found to have mean positive detrital carbon flux (Fig. 2, Table 1). Conversely, at Conch Reef, significant consumption of detritus was found for Callyspongia plicifera $(t=3.74, \mathrm{df}=6, \mathrm{p}=0.010)$ and $I$. strobilina $(t=7.60$, $\mathrm{df}=2, \mathrm{p}=0.017$ ), while detritus uptake for all other species was marginally significant or nonsignificant (Agelas tubulata: $t=2.34, \mathrm{df}=5, \mathrm{p}=0.067 ; C$. vaginalis: $t=2.01, \mathrm{df}=4, \mathrm{p}=0.115$; . laxissima: $t=2.23$, $\mathrm{df}=5, \mathrm{p}=0.076$; Niphates digitalis: $t=2.59, \mathrm{df}=3, \mathrm{p}=$ 0.081 ; V. gigantea: $t=2.48, \mathrm{df}=4, \mathrm{p}=0.069$; Xestospongia muta: $t=1.78, \mathrm{df}=3, \mathrm{p}=0.173$ ) (Fig. $2 \mathrm{a}$, 
Table 1. Mean $( \pm 95 \%$ CI) sponge volumes, pumping rates, and carbon fluxes mediated by Caribbean coral reef sponges studied in situ at Conch Reef, Key Largo, Florida, USA and Carrie Bow Cay, Belize. Sponges are identified as high microbial abundance (HMA) and low microbial abundance (LMA) species. Food types considered were dissolved organic carbon (DOC), detritus (DET), and live particulate organic carbon (LPOC). Negative values indicate net excretion and positive values indicate net consumption of a particular food type. '\% total carbon uptake' is the percent contribution of each food type to the specific filtration rate for total organic carbon. n: number of samples. Significant differences between incurrent and excurrent concentrations of detritus are indicated by an asterisk: ${ }^{*} \mathrm{p}<0.05$, paired $t$-test

\begin{tabular}{|c|c|c|c|c|c|c|c|}
\hline Location and species & $\begin{array}{c}\text { Sponge } \\
\text { volume (l) }\end{array}$ & $\begin{array}{l}\text { Pumping rate } \\
\left(1 \mathrm{~s}^{-1} \mathrm{l}^{-1} \text { sponge }\right)\end{array}$ & $\begin{array}{l}\text { Food } \\
\text { type }\end{array}$ & $\mathrm{n}$ & $\begin{array}{l}\text { Carbon consumed } \\
\left.\text { ( } \mu \mathrm{mol} \mathrm{l^{-1 }} \text { seawater }\right)\end{array}$ & $\begin{array}{l}\text { Specific filtration rate } \\
\left(\mathrm{nmol} \mathrm{C} \mathrm{s}{ }^{-1} \mathrm{l}^{-1} \text { sponge }\right)\end{array}$ & $\begin{array}{c}\% \text { total carbon } \\
\text { uptake }\end{array}$ \\
\hline $\begin{array}{l}\text { Conch Reef } \\
\text { Agelas tubulata } \\
\text { (HMA) }\end{array}$ & $2.38 \pm 1.47$ & $0.01 \pm 0.003$ & $\begin{array}{l}\text { DOC } \\
\text { DET } \\
\text { LPOC }\end{array}$ & $\begin{array}{l}6 \\
6 \\
6\end{array}$ & $\begin{array}{l}13.1 \pm 27.7 \\
2.84 \pm 2.38 \\
3.20 \pm 1.08\end{array}$ & $\begin{array}{r}196 \pm 406 \\
36 \pm 40.1 \\
30.3 \pm 10.4\end{array}$ & $\begin{array}{l}75 \\
14 \\
12\end{array}$ \\
\hline $\begin{array}{l}\text { Ircinia strobilina } \\
\text { (HMA) }\end{array}$ & $2.86 \pm 3.65$ & $0.005 \pm 0.006$ & $\begin{array}{l}\text { DOC } \\
\text { DET } \\
\text { LPOC }\end{array}$ & $\begin{array}{l}2 \\
3 \\
3\end{array}$ & $\begin{aligned} 17 & \pm 17 \\
7.17 & \pm 1.85 \\
3.15 & \pm 0.40\end{aligned}$ & $\begin{aligned} 135 & \pm 188 \\
30 & \pm 26.8^{*} \\
15.8 & \pm 17\end{aligned}$ & $\begin{array}{c}75 \\
17 \\
9\end{array}$ \\
\hline $\begin{array}{l}\text { Verongula gigantea } \\
\text { (HMA) }\end{array}$ & $9.95 \pm 7.22$ & $0.055 \pm 0.025$ & $\begin{array}{l}\text { DOC } \\
\text { DET } \\
\text { LPOC }\end{array}$ & $\begin{array}{l}6 \\
5 \\
5\end{array}$ & $\begin{array}{l}9.68 \pm 23.9 \\
1.45 \pm 1.15 \\
2.86 \pm 1.44\end{array}$ & $\begin{aligned} 529 & \pm 1395 \\
70.3 & \pm 43.5 \\
140 & \pm 105\end{aligned}$ & $\begin{array}{l}71 \\
10 \\
19\end{array}$ \\
\hline $\begin{array}{l}\text { V. reiswigi } \\
\text { (HMA) }\end{array}$ & $9.52 \pm 15.5$ & $0.001 \pm 0.001$ & $\begin{array}{l}\text { DOC } \\
\text { DET } \\
\text { LPOC }\end{array}$ & $\begin{array}{l}2 \\
1 \\
1\end{array}$ & $\begin{array}{c}-13.5 \pm 16.9 \\
-5.98 \\
4.07\end{array}$ & $\begin{array}{c}-7.27 \pm 0.66 \\
-8.44 \\
5.75\end{array}$ & $\begin{array}{c}0 \\
0 \\
100\end{array}$ \\
\hline $\begin{array}{l}\text { Xestospongia muta } \\
\text { (HMA) }\end{array}$ & $31.5 \pm 25.3$ & $0.027 \pm 0.017$ & $\begin{array}{l}\text { DOC } \\
\text { DET } \\
\text { LPOC }\end{array}$ & $\begin{array}{l}5 \\
4 \\
4\end{array}$ & $\begin{array}{r}-5.94 \pm 38.6 \\
0.94 \pm 1.03 \\
1.79 \pm 0.24\end{array}$ & $\begin{array}{c}191 \pm 731 \\
31.3 \pm 45.7 \\
37.7 \pm 25.3\end{array}$ & $\begin{array}{l}74 \\
12 \\
14\end{array}$ \\
\hline $\begin{array}{l}\text { Callyspongia plicifera } \\
\text { (LMA) }\end{array}$ & $0.39 \pm 0.16$ & $0.104 \pm 0.031$ & $\begin{array}{l}\text { DOC } \\
\text { DET } \\
\text { LPOC }\end{array}$ & $\begin{array}{l}7 \\
7 \\
7\end{array}$ & $\begin{array}{r}-0.70 \pm 15.6 \\
1.12 \pm 0.59 \\
2.66 \pm 1.12\end{array}$ & $\begin{array}{c}2.43 \pm 1615 \\
123 \pm 78.5^{*} \\
278 \pm 126\end{array}$ & $\begin{array}{c}1 \\
30 \\
69\end{array}$ \\
\hline $\begin{array}{l}\text { C. vaginalis } \\
\text { (LMA) }\end{array}$ & $0.07 \pm 0.02$ & $0.05 \pm 0.051$ & $\begin{array}{l}\text { DOC } \\
\text { DET } \\
\text { LPOC }\end{array}$ & $\begin{array}{l}5 \\
5 \\
5\end{array}$ & $\begin{aligned}-4.85 & \pm 20.9 \\
1.15 & \pm 1.13 \\
2.33 & \pm 0.5\end{aligned}$ & $\begin{array}{r}8.69 \pm 438 \\
94.1 \pm 173 \\
128 \pm 147\end{array}$ & $\begin{array}{c}4 \\
41 \\
55\end{array}$ \\
\hline $\begin{array}{l}\text { Mycale laxissima } \\
\text { (LMA) }\end{array}$ & $0.49 \pm 0.23$ & $0.003 \pm 0.003$ & $\begin{array}{l}\text { DOC } \\
\text { DET } \\
\text { LPOC }\end{array}$ & $\begin{array}{l}6 \\
6 \\
6\end{array}$ & $\begin{aligned}-5.31 & \pm 17 \\
1.03 & \pm 0.9 \\
1.84 & \pm 0.32\end{aligned}$ & $\begin{array}{r}-13.5 \pm 43.1 \\
2.83 \pm 2.37 \\
5.11 \pm 1.46\end{array}$ & $\begin{array}{c}0 \\
36 \\
64\end{array}$ \\
\hline $\begin{array}{l}\text { Niphates digitalis } \\
\text { (LMA) }\end{array}$ & $0.49 \pm 0.22$ & $0.127 \pm 0.053$ & $\begin{array}{l}\text { DOC } \\
\text { DET } \\
\text { LPOC }\end{array}$ & $\begin{array}{l}6 \\
4 \\
5\end{array}$ & $\begin{array}{r}-22.3 \pm 24.6 \\
1.49 \pm 1.13 \\
2.29 \pm 0.31\end{array}$ & $\begin{aligned}-2389 & \pm 2791 \\
192 & \pm 162 \\
358 & \pm 146\end{aligned}$ & $\begin{array}{c}0 \\
35 \\
65\end{array}$ \\
\hline $\begin{array}{l}\text { Carrie Bow Cay } \\
\text { A. tubulata } \\
\text { (HMA) }\end{array}$ & $3.67 \pm 2.38$ & $0.005 \pm 0.003$ & $\begin{array}{l}\text { DOC } \\
\text { DET } \\
\text { LPOC }\end{array}$ & $\begin{array}{l}6 \\
5 \\
6\end{array}$ & $\begin{array}{l}7.63 \pm 19.4 \\
0.47 \pm 0.47 \\
1.61 \pm 0.21\end{array}$ & $\begin{array}{l}36.4 \pm 80.6 \\
1.72 \pm 2.37 \\
7.33 \pm 3.46\end{array}$ & $\begin{array}{c}80 \\
4 \\
16\end{array}$ \\
\hline $\begin{array}{l}\text { V. gigantea } \\
\text { (HMA) }\end{array}$ & $24.5 \pm 35.9$ & $0.055 \pm 0.001$ & $\begin{array}{l}\text { DOC } \\
\text { DET } \\
\text { LPOC }\end{array}$ & $\begin{array}{l}2 \\
1 \\
1\end{array}$ & $\begin{array}{c}7.98 \pm 9.07 \\
-3.66 \\
0.67\end{array}$ & $\begin{array}{l}439 \pm 499 \\
-201 \\
36.8\end{array}$ & $\begin{array}{c}92 \\
0 \\
8\end{array}$ \\
\hline $\begin{array}{l}\text { V. reiswigi } \\
\text { (HMA) }\end{array}$ & $7.68 \pm 3.77$ & $0.004 \pm 0.003$ & $\begin{array}{l}\text { DOC } \\
\text { DET } \\
\text { LPOC }\end{array}$ & $\begin{array}{l}3 \\
3 \\
3\end{array}$ & $\begin{array}{l}17.9 \pm 28.5 \\
0.61 \pm 0.17 \\
1.58 \pm 0.002\end{array}$ & $\begin{array}{l}116 \pm 208 \\
2.68 \pm 2.13^{*} \\
6.67 \pm 4.3\end{array}$ & $\begin{array}{c}93 \\
2 \\
5\end{array}$ \\
\hline $\begin{array}{l}X . \text { muta } \\
\text { (HMA) }\end{array}$ & $40 \pm 16.6$ & $0.008 \pm 0.006$ & $\begin{array}{l}\text { DOC } \\
\text { DET } \\
\text { LPOC }\end{array}$ & $\begin{array}{l}5 \\
4 \\
4\end{array}$ & $\begin{array}{r}-7.45 \pm 24.1 \\
0.56 \pm 0.17 \\
1.36 \pm 0.10\end{array}$ & $\begin{array}{c}-91.3 \pm 180 \\
4.31 \pm 2.61^{*} \\
12 \pm 9.3\end{array}$ & $\begin{array}{c}0 \\
27 \\
73\end{array}$ \\
\hline $\begin{array}{l}\text { C. plicifera } \\
\text { (LMA) }\end{array}$ & $0.87 \pm 0.48$ & $0.095 \pm 0.032$ & $\begin{array}{l}\text { DOC } \\
\text { DET } \\
\text { LPOC }\end{array}$ & $\begin{array}{l}5 \\
5 \\
5\end{array}$ & $\begin{array}{c}-3.61 \pm 16.1 \\
1.11 \pm 1.4 \\
1.36 \pm 0.26\end{array}$ & $\begin{aligned}-741 & \pm 1743 \\
138 & \pm 207 \\
122 & \pm 30.5\end{aligned}$ & $\begin{array}{c}0 \\
53 \\
47\end{array}$ \\
\hline $\begin{array}{l}\text { C. vaginalis } \\
\text { (LMA) }\end{array}$ & $1.7 \pm 1.04$ & $0.057 \pm 0.046$ & $\begin{array}{l}\text { DOC } \\
\text { DET } \\
\text { LPOC }\end{array}$ & $\begin{array}{l}5 \\
5 \\
5\end{array}$ & $\begin{array}{r}-12.7 \pm 15.9 \\
0.78 \pm 0.47 \\
1.36 \pm 0.28\end{array}$ & $\begin{aligned}-897 & \pm 655 \\
44.9 & \pm 30.8^{*} \\
73.5 & \pm 61.2\end{aligned}$ & $\begin{array}{c}0 \\
38 \\
62\end{array}$ \\
\hline $\begin{array}{l}\text { M. laxissima } \\
\text { (LMA) }\end{array}$ & $1.29 \pm 0.54$ & $0.002 \pm 0.0004$ & $\begin{array}{l}\text { DOC } \\
\text { DET } \\
\text { LPOC }\end{array}$ & $\begin{array}{l}5 \\
5 \\
5\end{array}$ & $\begin{array}{r}-1.55 \pm 10.1 \\
-0.08 \pm 1.39 \\
1.01 \pm 0.33\end{array}$ & $\begin{array}{r}-8.14 \pm 17.8 \\
-0.43 \pm 3.37 \\
2.38 \pm 1.01\end{array}$ & $\begin{array}{c}0 \\
0 \\
100\end{array}$ \\
\hline $\begin{array}{l}\text { N. digitalis } \\
\text { (LMA) }\end{array}$ & $1.79 \pm 1.07$ & $0.082 \pm 0.083$ & $\begin{array}{l}\text { DOC } \\
\text { DET } \\
\text { LPOC }\end{array}$ & $\begin{array}{l}4 \\
4 \\
4\end{array}$ & $\begin{array}{l}-3.2 \pm 29.6 \\
1.34 \pm 1.72 \\
1.41 \pm 0.47\end{array}$ & $\begin{aligned}-134 & \pm 820 \\
214 & \pm 404 \\
73.6 & \pm 67.7\end{aligned}$ & $\begin{array}{c}0 \\
74 \\
26\end{array}$ \\
\hline
\end{tabular}



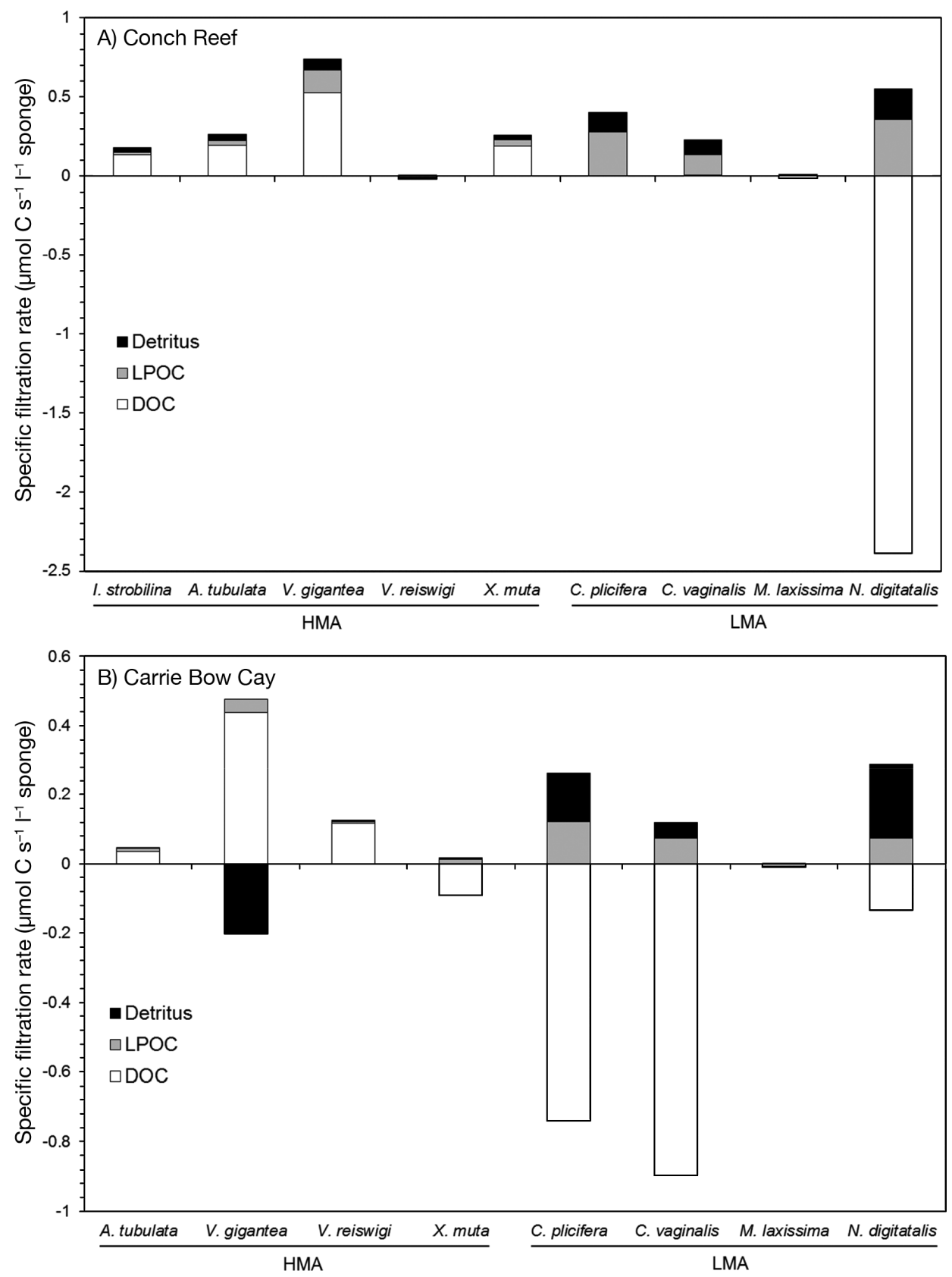

Fig. 2. Mean specific filtration rates for dissolved organic carbon (DOC), live particulate organic carbon (LPOC), and detritus by high microbial abundance (HMA) and low microbial abundance (LMA) sponge species at (A) Conch Reef, Key Largo, FL, and (B) Carrie Bow Cay, Belize. See Table 1 for full species names and sample sizes

Table 1). At Carrie Bow Cay, detritus consumption was significant for $C$. vaginalis $(t=3.24, \mathrm{df}=4, \mathrm{p}=$ $0.032), V$. reiswigi $(t=7.06, \mathrm{df}=2, \mathrm{p}=0.019)$, and $X$. muta $(t=6.49, \mathrm{df}=3, \mathrm{p}=0.007)$, but was not significant for A. tubulata $(t=1.96, \mathrm{df}=4, \mathrm{p}=0.122)$, . plicifera $(t=1.55, \mathrm{df}=4, \mathrm{p}=0.196)$, and $N$. digitalis $(t=$ 1.53, $\mathrm{df}=3, \mathrm{p}=0.223$ ) (Fig. 2b, Table 1).

Specific filtration rates were significantly greater at Conch Reef relative to Carrie Bow Cay $(H=8.4, \mathrm{df}=1$, $\mathrm{p}<0.01$ ), and significantly differed between carbon pools $(H=16.9, \mathrm{df}=2, \mathrm{p}<0.001)$ and between species $(H=25.8, \mathrm{df}=5, \mathrm{p}<0.001)$. There was particularly high inter- and intraspecific variability in spongemediated flux of DOC, especially for the LMA sponges C. plicifera, C. vaginalis, and N. digitalis; however, all 2- and 3-way interactions between variables were nonsignificant ( $p>0.05$; Fig. 2, Table 1). HMA sponges generally obtained carbon in the form of 


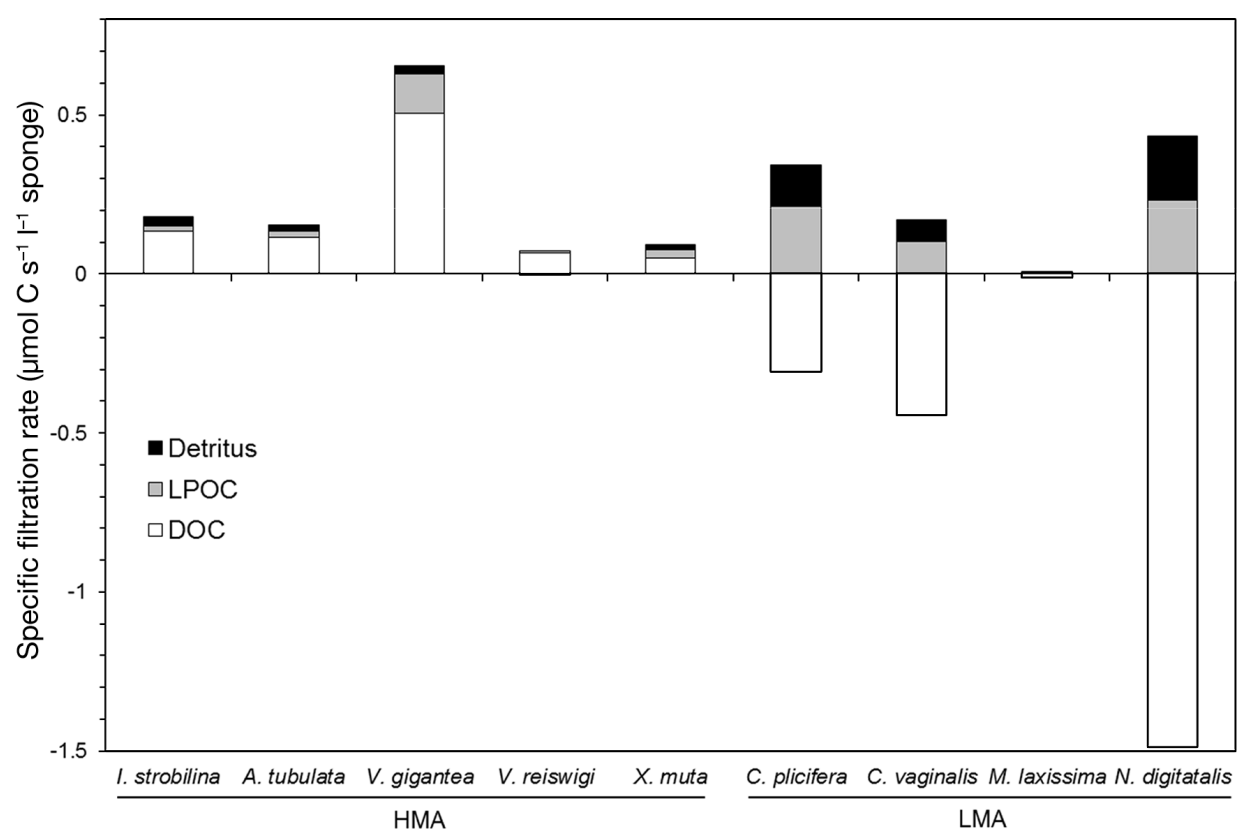

Fig. 3. Mean specific filtration rates at both study locations (Conch Reef, Key Largo, FL, and Carrie Bow Cay, Belize) for dissolved organic carbon (DOC), live particulate organic carbon (LPOC), and detritus by HMA and LMA sponge species (see Fig. 2 legend for definitions). See Table 1 for full species names and sample sizes

DOC, while LMA sponges were generally net sources of DOC, with a diet that primarily consisted of LPOC and detritus (Fig. 3). Considering both locations combined, DOC accounted for 75, 75, 77, 91, and $54 \%$ of mean total carbon uptake for the HMA sponges $A$. tubulata, I. strobilina, V. gigantea, V. reiswigi, and $X$. muta, respectively, while the proportions of mean total carbon uptake in the form of LPOC and detritus by LMA sponges were, respectively, 62 and $38 \%$ for C. plicifera, 59 and $41 \%$ for C. vaginalis, 74 and $26 \%$ for M. laxissima, and 53 and $47 \%$ for $N$. digitalis.

Ordinary least squares regression was used to assess the variability of DOC flux by examining the relationship between DOC specific filtration rates and $\log _{\mathrm{e}}$-transformed incurrent DOC concentration. There was a significant direct relationship between the flux of DOC and the concentration of DOC in ambient seawater for the HMA sponges A. tubulata, $V$. gigantea, and $V$. reiswigi (Fig. 4) and the LMA sponge C. plicifera (Fig. 5), but not for the sponges $X$. muta, C. vaginalis, $N$. digitalis, or M. laxissima.

\section{DISCUSSION}

Just as the functional role of microbes in recycling DOM was found to explain the paradox of abundant planktonic life in oligotrophic seas (Pomeroy et al. 2007), another long-overlooked group, the Porifera, may underpin the high productivity of biodiverse coral reefs in desert-like tropical seas via the spongeloop (de Goeij et al. 2013). In fact, it has been suggested that DOM turnover by encrusting coral reef cavity sponges alone is on par with estimates of the daily gross primary production of the entire reef ecosystem (de Goeij et al. 2008b), and that a large portion of assimilated DOM is subsequently released as detritus (de Goeij et al. 2013, Alexander et al. 2014, Rix et al. 2016, 2017). The putative ecological significance of the sponge-loop is even more impressive when one considers that, with one exception (McMurray et al. 2016), DOM turnover and detritus production has yet to be considered for the massive, emergent sponge species that dominate the surface of Caribbean coral reefs and represent a large proportion of sponge community biomass. While DOC uptake by emergent sponges was observed in the present study, particularly by HMA sponge species, no sponge species was found to produce significant quantities of detritus; thus, the sponge-loop, as originally proposed, may be limited to encrusting sponges found in the interstices of coral reefs.

In retrospect, these findings may not be especially surprising considering the proposed mechanism and high rates of sponge detritus production observed for encrusting sponge species. The growth of cryptic, encrusting sponge species is thought to be negligible, limited by high competition for available sub- 

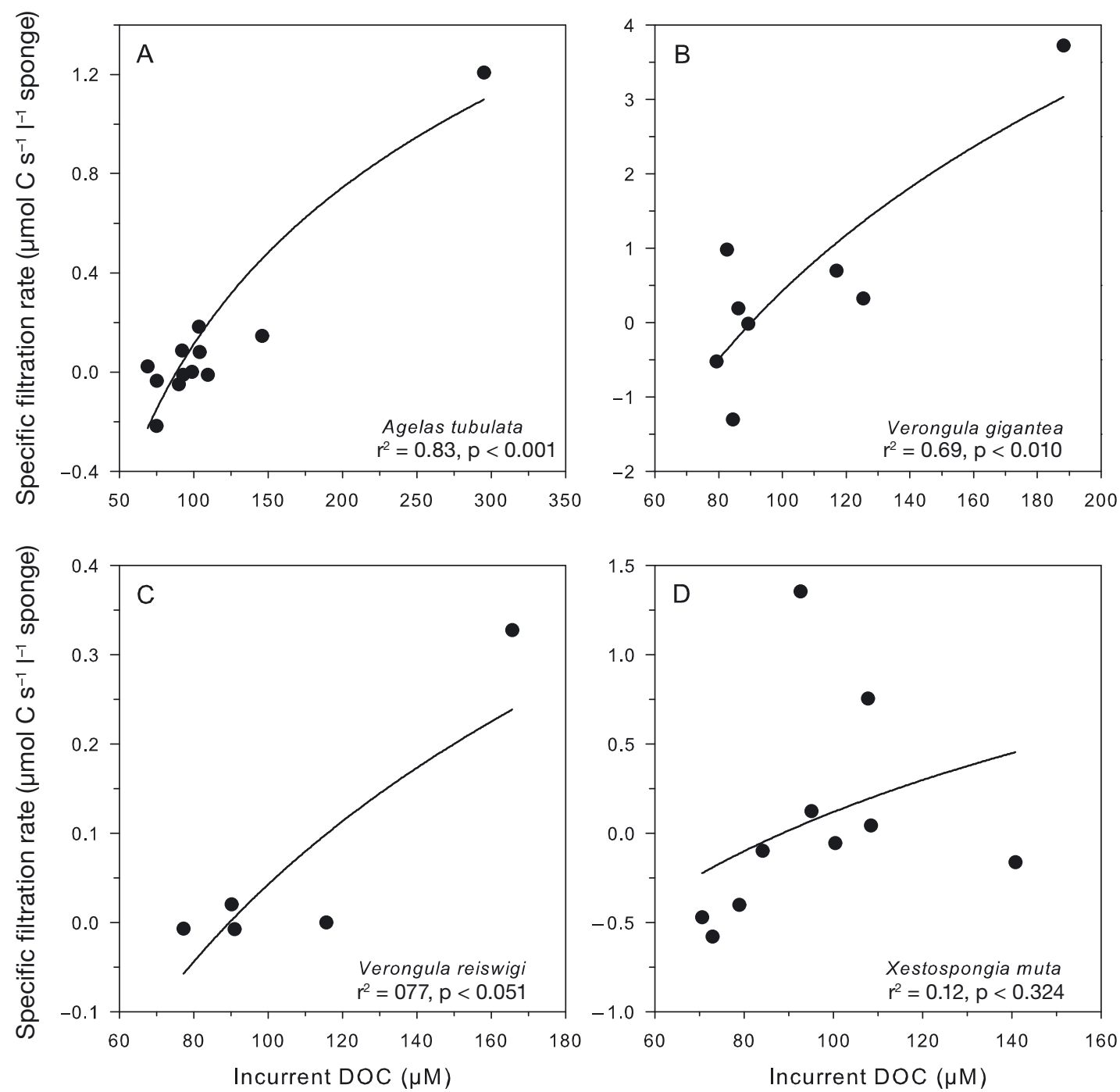

Fig. 4. Relationship between specific filtration rate and the abundance of dissolved organic carbon (DOC) for HMA sponges (see Fig. 2 legend for definition): (A) Agelas tubulata, (B) Verongula gigantea, (C) V. reiswigi, and (D) Xestospongia muta

strata; yet, these species consume DOC at high rates and DOC frequently constitutes $>90 \%$ of total organic carbon uptake (de Goeij et al. 2008b, 2013). Instead of growing, it is hypothesized that detritus production results from the rapid proliferation and shedding of cells, primarily choanocytes (de Goeij et al. 2009, 2013, Alexander et al. 2014, 2015), but may also include digestive waste products (Kahn \& Leys 2016, Maldonado 2016). This process is energetically costly, and may represent $75 \%$ of the total organic carbon (DOC and POC) assimilated (Kahn \& Leys 2016). Moreover, it has been estimated that up to $40 \%$ of the DOC consumed by cryptic sponges is released as detritus (Rix et al. 2016). Therefore, if massive, emergent sponge species exhibit similarly rapid cell proliferation and shedding, one would expect to observe: (1) minimal sponge growth; and, if rates of detritus production for encrusting species are scaled up to the much larger biomass of emergent species, (2) discharge of detritus in the excurrent seawater of emergent species. We maintain that there is little evidence to support these predictions. Massive, emergent sponges often display substantial growth (e.g. Reiswig 1973, McMurray et al. 2008); moreover, in contrast to detritus production by encrusting species at rates sufficient to permit daily collection via pipette (Alexander et al. 2014), we have not observed the discharge of detritus from massive species in the field. Detritus production has been found to decrease as sponges regenerate from tissue damage (Alexander et al. 2015); however we employed In-Ex methods that do not require sponge manipulation and only included individuals with no obvious signs of disease or tissue damage. We hypothesize that, un- 

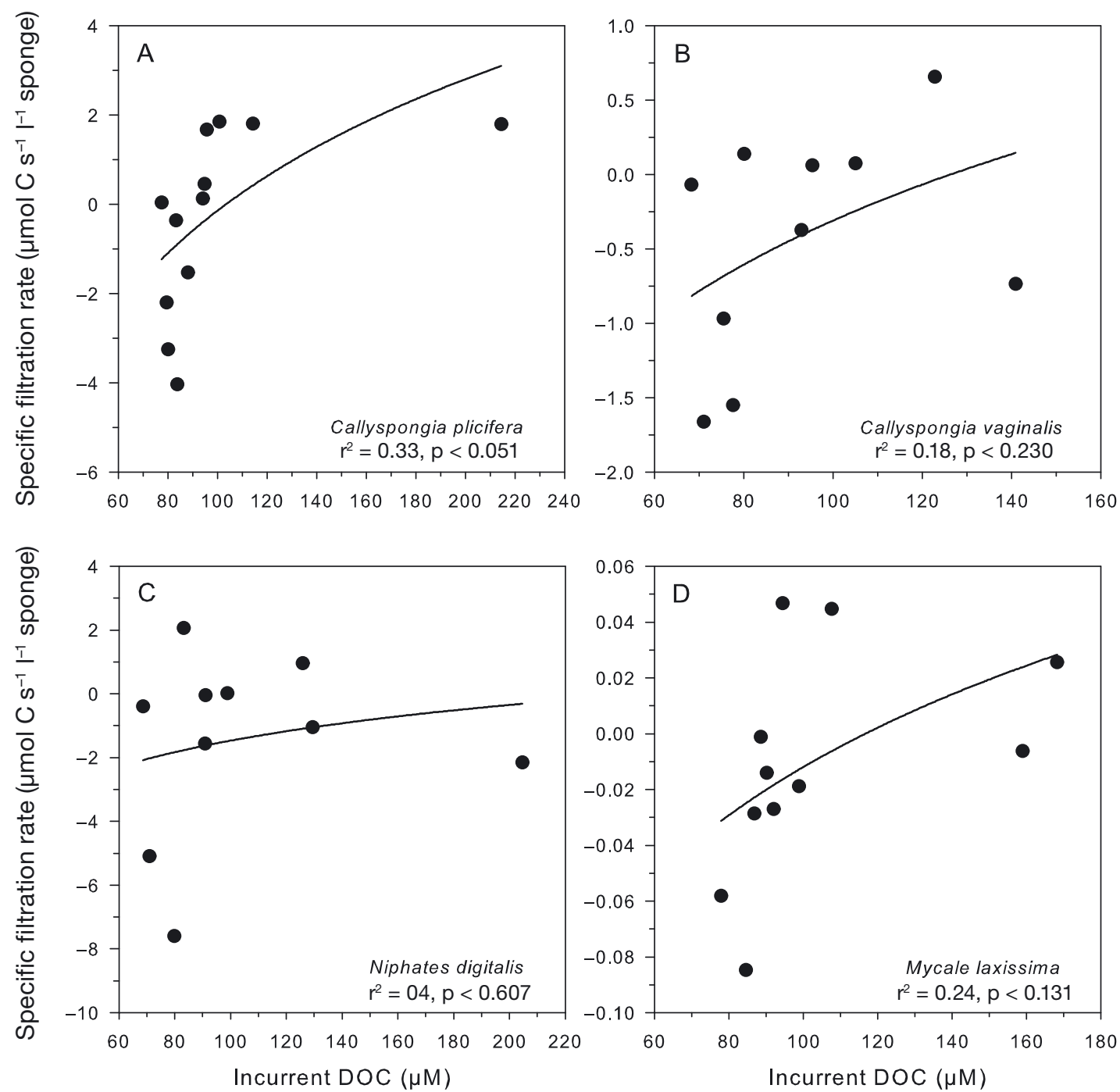

Fig. 5. Relationship between specific filtration rate and the abundance of dissolved organic carbon (DOC) for LMA sponges (see Fig. 2 legend for definition): (A) Callyspongia plicifera, (B) C. vaginalis, (C) Niphates digitalis, and (D) Mycale laxissima

like encrusting species which are largely limited to growth in 2 dimensions, emergent species divert assimilated carbon from DOC to biomass production instead of cell turnover and detritus production.

Low DOC uptake by emergent sponges, relative to encrusting species, is likely an additional factor that may explain the lack of detritus production observed in this study. Our estimates of DOC flux for Xestospongia muta on Conch Reef $\left(0.19 \pm 0.73 \mu \mathrm{mol} \mathrm{C} \mathrm{s}{ }^{-1}\right.$

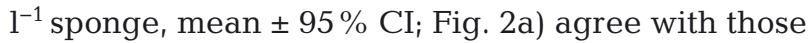
found for the same species at the same location $\left(0.53 \pm 0.42 \mu \mathrm{mol} \mathrm{C} \mathrm{s}{ }^{-1} \mathrm{l}^{-1}\right.$ sponge, mean $\left.\pm \mathrm{SE}\right)$ by Hoer et al. (2018), and DOC flux for the emergent species Theonella swinhoei $\left(0.43 \pm 0.30 \mu \mathrm{mol} \mathrm{C} \mathrm{s}{ }^{-1}\right.$ $\mathrm{l}^{-1}$, sponge, mean $\pm \mathrm{SD}_{\text {; }}$ Yahel et al. 2003) is within the range we found for the HMA species investigated (Figs. 2 \& 3); however, these estimates are approxi- mately an order of magnitude lower than those reported for cryptic, encrusting species that produce detritus $(3.64 \pm 0.69,4.22 \pm 0.25$, and $3.78 \pm 0.67 \mu \mathrm{mol}$ $\mathrm{C} \mathrm{s}^{-1} \mathrm{l}^{-1}$ sponge, mean $\pm \mathrm{SD}$, for Halisarca caerulea, Mycale microsigmatosa, and Merlia normani, respectively; de Goeij et al. 2008b, 2013). The estimates of DOC flux for emergent species reported here also appear lower than those found for encrusting species inhabiting temperate Mediterranean reefs, although DOC fluxes were standardized to sponge area and not volume, making it problematic to compare with the data presented here (Morganti et al. 2017). Although sponge-mediated DOC uptake is commonly reported in the literature, there is unfortunately limited information on rates of sponge-mediated DOC flux standardized to sponge tissue volume, making further comparisons difficult. 
The concentration and composition of DOC available affects rates of DOC uptake and transformation by sponges and may partly explain conflicting findings for encrusting versus emergent sponge species. It is thought that sponges primarily consume labile, rather than refractory, forms of DOC (Yahel et al. 2003, de Goeij et al. 2008b), and higher rates of uptake and detritus production have been found for sponges incubated with algal- versus coral-derived DOC (Rix et al. 2017). Evidence suggests that there may be a direct relationship between ambient DOC concentrations and DOC uptake, and there may be a threshold for DOC uptake (Mueller et al. 2014, McMurray et al. 2016, 2017, Archer et al. 2017, Morganti et al. 2017). Our results only support such a relationship for the HMA species Agelas tubulata, Verongula reiswigi, V. gigantea, and the LMA species Callyspongia plicifera, although additional data are needed to further examine this putative relationship for the species investigated. A direct relationship between DOC availability and consumption may indicate that microbes are primarily involved in DOM uptake (Middelburg 2015); however, microbes and sponge cells may also differentially assimilate different DOC fractions (Rix et al. 2017), which may explain the lack of a relationship for the other 4 species considered. Finally, given lower rates of DOC uptake by emergent sponge species, and approximately equivalent dissolved oxygen demand for emergent and encrusting species (Reiswig 1974, 1981, Yahel et al. 2003, de Goeij et al. 2008b, Hoer et al. 2018), a larger proportion of consumed DOC may be used to satisfy respiration demands by emergent species relative to encrusting species, allowing for carbon accumulation and cell turnover by the latter (see Hoer et al. 2018 for discussion).

Is it possible that significant detritus production by the emergent sponges sampled in this study was somehow overlooked as a consequence of using InEx methods? For example, it is currently unknown if detritus production varies temporally; if detritus was released by sponges episodically, then it may have been missed within the relatively short sampling interval that was employed in this study (de Goeij et al. 2017). This seems unlikely, given the number of replicates that have been analyzed in this study, and in previous studies of $X$. muta in which excurrent detritus was also not detected (McMurray et al. 2016). Further, Yahel et al. (2003) was able to detect excurrent detritus from the Red Sea sponge T. swinhoei using similar In-Ex sampling methods. Other techniques that have been used to study sponge detritus production (de Goeij et al. 2017) involve the place- ment of sponges in open pots or flow chambers and the subsequent collection of detritus from the sponge surface and the bottom surface of open pots via pipette (Alexander et al. 2014) or by filtering the volume of seawater in the chamber through a GF/F filter after a sufficient interval of time (de Goeij et al. 2013, Rix et al. 2016, 2017). The deposition of sponge-produced detritus in aquaria or incubation chambers (e.g. de Goeij et al. 2013, Alexander et al. 2014) might suggest that it is emitted by sponges as clumps or larger particles that exceed $100 \mu \mathrm{m}$ in size, potentially larger than the pre-filter used in this study. However, seawater samples analyzed in the present study were expelled from syringes through $100 \mu \mathrm{m}$ mesh suspended in air within a filtration funnel, resulting in a great deal of shear that would break-up any aggregated or flocculated detritus that might be present, but retain potential contaminants such as zooplankton. Further, no aggregates of detritus were ever observed on the surface of the white mesh while processing samples for this study. It should also be noted that even relatively small particles $(<50 \mu \mathrm{m})$ sink and contribute to the vertical flux of detrital carbon in marine systems (Gowing \& Silver 1985). Bacterial colonization and the aggregation of detritus emitted by sponges may further contribute to detrital deposition (Biddanda \& Pomeroy 1988), and the nitrogen contribution by colonizing bacteria has been invoked to explain the lower $\mathrm{C}: \mathrm{N}$ ratio of sponge-produced detritus relative to the DOM consumed by sponges (de Goeij et al. 2017). There is little information on the physical nature of spongeproduced detritus; however particles $<8 \mu \mathrm{m}$ have been detected in excurrent seawater using flow cytometry (Yahel et al. 2003, McMurray et al. 2016), and Wolfrath \& Barthel (1989) reported that the sponge Halichondrea panacea excreted detritus in the form of spherical fecal pellets with diameters that ranged from 10 to $55 \mu \mathrm{m}$ when fed microspheres and unicellular algae. Examinations of detritus within the lumen of sponge excurrent canals have additionally revealed that the detritus has a complex composition and includes choanocytes, archeocytes, spherulous cells, granular cells, and exocytosed vesicles, all generally $<10 \mu \mathrm{m}$ in diameter (Maldonado 2016), and that, closer to the oscula, this detritus may occur as mucal sheets of cellular debris (Alexander et al. 2014).

While we did not detect significant net detritus production, it is important to note that some individual sponges did produce measureable detritus. Sponge detritus includes both debris resulting from cell turnover and digestive wastes (Maldonado 2016). For the 
few individuals with negative detrital flux, the concentration of carbon emitted was generally small; therefore, we hypothesize that, similar to conclusions reached by Kahn \& Leys (2016) for work on explants of 4 cold-water sponge species, the detritus released by massive species is likely produced as waste, rather than cellular debris resulting from rapid cell turnover. Given the indirect method of quantifying detritus used here, it is impossible to distinguish sponge-generated detritus from incurrent detritus. Therefore, it is possible that individuals that are net consumers of detritus also produce detritus, but at rates lower than detritus consumption. Some sponge species are also known to harbor invertebrate symbionts such as shrimps and brittle stars (e.g. Henkel \& Pawlik 2005), and it is unknown whether endosymbiotic macrofauna consume sponge-produced detritus in excurrent canals before it can be released from the sponge. However, these symbiotic relationships are highly variable across sponge species (and are often species-specific); if detrital consumption within the sponge was taking place, it is likely that divergent results would have been obtained across the sponge species studied herein. In any case, the ecological relevance of detritus production by emergent sponge species is questionable if there is overall net removal of detritus from the water-column and production does not approach the levels originally suggested for encrusting species (de Goeij et al. 2013).

Our findings support the general paradigm that the diet of HMA species primarily consists of DOC (e.g. Hoer et al. 2018), while LMA species have greater reliance on dead and live POC in the form of picoplankton (Maldonado et al. 2012). However, we note that this may not hold for LMA species with encrusting morphologies, as significant amounts of DOC uptake have been found for a number of species (de Goeij et al. 2008b, 2013, Rix et al. 2016, 2017, Morganti et al. 2017; but see Ribes et al. 1999, 2012). HMA species have a variety of traits, including slower pumping rates and denser tissue, which increase the time of seawater contact within the aquiferous system and may aid in higher DOC uptake relative to LMA species (Weisz et al. 2008). Intraspecific rates of DOC flux were especially variable; this may be due to variability in the concentration and composition of ambient DOC (see above), but may also reflect differences in the sponge microbiome (Fiore et al. 2013). Although the relative role of microbes versus sponge cells in DOC processing remains unresolved, higher rates of DOC uptake by HMA versus LMA species is consistent with the view that DOC processing is, at least in part, mediated by symbiotic microbes (Hoer et al. 2018). Nonetheless, the ability of LMA species to process DOC, albeit at lower and variable rates, may also indicate that sponge cells have a direct role; and tracer experiments have shown that both sponge cells and microbes assimilate DOC (de Goeij et al. 2008a, Rix et al. 2016, 2017). While a correlation between picoplankton abundance and sponge growth (as tube elongation) has been used to suggest that food is limiting for Caribbean coral reef sponges (Lesser \& Slattery 2013, Slattery \& Lesser 2015), this conclusion has been contested (Pawlik et al. 2013, 2015a,b). Considering that the diets of both the HMA and LMA species examined here were found to be broader than initially assumed under the food limitation hypothesis, and include both DOC and detritus, we maintain that the abundance of picoplankton alone is not an appropriate metric with which to assess food limitation.

Despite a lack of evidence for the production of detritus by massive, emergent sponge species investigated here, the rates of DOC uptake by HMA sponges likely signify a similarly important, but different, trophic pathway from that originally described for the sponge-loop hypothesis. The bioavailable product of DOC assimilation by cryptic sponge species is detritus that is available to detritivores and suspension feeders (de Goeij et al. 2009, 2013, Alexander et al. 2014, 2015), while emergent sponge species return carbon to the benthos in the form of biomass that feeds spongivorous fishes, turtles, and invertebrates. Not all of the sponge biomass produced by emergent sponge species is available to higher trophic levels, as some species invest resources into the production of secondary metabolites that deter predation; however, species that lack chemical defenses grow and reproduce at faster rates and are grazed upon by spongivorous predators (Pawlik 2011). In contrast, chemically defended individuals that grow relatively slowly and may be longlived (McMurray et al. 2008) may be important for the sequestration and storage of carbon as biomass.

Our evidence of detritus uptake by a number of emergent sponge species, and mean production of DOC by emergent LMA species, may indicate even further complexity in the trophic relationships mediated by sponges. For example, it remains unknown whether detritus production by cryptic species may be feeding emergent sponge species, and whether DOC released by LMA species may be feeding emergent HMA and cryptic LMA species in a manner similar to the partial trophic niche separation of HMA and LMA species recently proposed on the basis of sponge nitrogen cycling (Morganti et al. 2017). Given 
the contrasting trophic pathways of DOC cycling by cryptic versus emergent coral reef sponges, and the diversity of trophic groups that may be ultimately fueled by this production, we conclude that the complexity and ecological importance of the sponge-loop may be even greater than originally proposed by de Goeij et al. (2013).

Acknowledgements. Research was supported by a National Science Foundation, Biological Oceanography Program, grant (OCE-1558580). The staff of Florida International University's Aquarius Reef Base in Key Largo, Florida, and the Smithsonian Institution's Carrie Bow Cay Field Station in Belize provided excellent logistical support. We thank J. McCall and R. Whitehead for assistance with seawater sample analysis, and L. Deignan, E. Fox, A. Scott, and M. Wooster for assistance in the field. Dr. Gitai Yahel and 2 anonymous reviewers provided constructive comments on an earlier version of the manuscript. Research in the Florida Keys National Marine Sanctuary was performed under permit FKNMS-2015-165; research conducted in Belize was performed under permit 000042-16 from the Belize Fisheries Department.

\section{LITERATURE CITED}

Alexander BE, Liebrand K, Osinga R, van der Geest HG and others (2014) Cell turnover and detritus production in marine sponges from tropical and temperate benthic ecosystems. PLOS ONE 9:e109486

Alexander BE, Achlatis M, Osinga R, van der Geest HG, Cleutjens JPM, Schutte B, de Goeij JM (2015) Cell kinetics during regeneration in the sponge Halisarca caerulea: How local is the response to tissue damage? PeerJ 3:e820

Archer SK, Stevens JL, Rossi RE, Matterson KO, Layman CA (2017) Abiotic conditions drive significant variability in nutrient processing by a common Caribbean sponge, Ircinia felix. Limnol Oceanogr 62:1783-1793

Azam F, Fenchel T, Field JG, Gray JC, Meyer-Reil LA, Thingstad F (1983) The ecological role of water-column microbes in the sea. Mar Ecol Prog Ser 10:257-263

Biddanda BA, Pomeroy LR (1988) Microbial aggregation and degradation of phytoplankton-derived detritus in seawater. I. Microbial succession. Mar Ecol Prog Ser 42: 79-88

Campbell L, Nolla HA, Vaulot D (1994) The importance of Prochlorococcus to community structure in the central North Pacific Ocean. Limnol Oceanogr 39:954-961

Cavender-Bares KK, Frankel SL, Chisholm SW (1998) A dual sheath flow cytometer for shipboard analyses of phytoplankton communities from the oligotrophic oceans. Limnol Oceanogr 43:1383-1388

* de Goeij JM, Moodley L, Houtekamer M, Carballeira NM, van Duyl FC (2008a) Tracing 13C-enriched dissolved and particulate organic carbon in the bacteria-containing coral reef sponge Halisarca caerulea: evidence for DOM feeding. Limnol Oceanogr 53:1376-1386

de Goeij JM, van den Berg H, van Oostveen MM, Epping EHG, van Duyl FC (2008b) Major bulk dissolved organic carbon (DOC) removal by encrusting coral reef cavity sponges. Mar Ecol Prog Ser 357:139-151 de Goeij JM, De Kluijver A, Van Duyl FC, Vacelet J and others (2009) Cell kinetics of the marine sponge Halisarca caerulea reveal rapid cell turnover and shedding. J Exp Biol 212:3892-3900

* de Goeij JM, van Oevelen D, Vermeij MJA, Osinga R, Middelburg JJ, de Goeij AFPM, Admiraal W (2013) Surviving in a marine desert: the sponge-loop retains resources within coral reefs. Science 342:108-110

de Goeij JM, Lesser MP, Pawlik JR (2017) Nutrient fluxes and ecological functions of coral reef sponges in a changing ocean. In: Carballo JL, Bell JJ (eds) Climate change, ocean acidification and sponges: impacts across multiple levels of organization. Springer International Publishing, Cham, p 373-410

* Ducklow HW, Kirchman DL, Quinby HL, Carlson CA, Dam HG (1993) Stocks and dynamics of bacterioplankton carbon during the spring bloom in the eastern North Atlantic Ocean. Deep Sea Res II 40:245-263

Fenchel T (2008) The microbial loop - 25 years later. J Exp Mar Biol Ecol 366:99-103

Fiore CL, Jarett JK, Lesser MP (2013) Symbiotic prokaryotic communities from different populations of the giant barrel sponge, Xestospongia muta. MicrobiologyOpen 2: 938-952

* Gloeckner V, Wehrl M, Moitinho-Silva L, Gernert C and others (2014) The HMA-LMA dichotomy revisited: an electron microscopical survey of 56 sponge species. Biol Bull 227:78-88

Gowing MM, Silver MW (1985) Minipellets: a new and abundant size class of marine fecal pellets. J Mar Res 43: 395-418

* Haas AF, Jantzen C, Naumann MS, Iglesias-Prieto R, Wild C (2010) Organic matter release by the dominant primary producers in a Caribbean reef lagoon: implication for in situ $\mathrm{O}_{2}$ availability. Mar Ecol Prog Ser 409:27-39

*Hadas E, Shpigel M, Ilan M (2009) Particulate organic matter as a food source for a coral reef sponge. J Exp Biol 212:3643-3650

Hansell DA, Carlson CA (2002) Biogeochemistry of marine dissolved organic matter. Academic Press, San Diego, CA

*Henkel TP, Pawlik JR (2005) Habitat use by spongedwelling brittlestars. Mar Biol 146:301-313

Hoer DR, Gibson PJ, Tommerdahl JP, Lindquist NL, Martens CS (2018) Consumption of dissolved organic carbon by Caribbean reef sponges. Limnol Oceanogr 63:337-351

Kahn AS, Leys SP (2016) The role of cell replacement in benthic-pelagic coupling by suspension feeders. R Soc Open Sci 3:160484

Lesser MP (2006) Benthic-pelagic coupling on coral reefs: feeding and growth of Caribbean sponges. J Exp Mar Biol Ecol 328:277-288

* Lesser MP, Slattery M (2013) Ecology of Caribbean sponges: Are top-down or bottom-up processes more important? PLOS ONE 8:e79799

Loh TL, Pawlik JR (2014) Chemical defenses and resource trade-offs structure sponge communities on Caribbean coral reefs. Proc Natl Acad Sci USA 111:4151-4156

Maldonado M (2016) Sponge waste that fuels marine oligotrophic food webs: a re-assessment of its origin and nature. Mar Ecol 37:477-491

Maldonado M, Ribes M, van Duyl FC (2012) Nutrient fluxes through sponges: biology, budgets, and ecological implications. In: Becerro MA, Uriz MJ, Maldonado M, Turon X (eds) Advances in sponge science: physiology, chemical 
and microbial diversity, biotechnology. Advances in Marine Biology, Vol. 62. Academic Press, Amsterdam, p 113-182

Marie D, Partensky F, Jacquet S, Vaulot D (1997) Enumeration and cell cycle analysis of natural populations of marine picoplankton by flow cytometry using the nucleic acid stain SYBR Green I. Appl Environ Microbiol 63:186-193

McMurray SE, Blum JE, Pawlik JR (2008) Redwood of the reef: growth and age of the giant barrel sponge Xestospongia muta in the Florida Keys. Mar Biol 155:159-171

McMurray SE, Pawlik JR, Finelli CM (2014) Trait-mediated ecosystem impacts: How morphology and size affect pumping rates of the Caribbean giant barrel sponge. Aquat Biol 23:1-13

* McMurray SE, Johnson ZI, Hunt DE, Pawlik JR, Finelli CM (2016) Selective feeding by the giant barrel sponge enhances foraging efficiency. Limnol Oceanogr 61: 1271-1286

McMurray SE, Pawlik JR, Finelli CM (2017) Demography alters carbon flux for a dominant benthic suspension feeder, the giant barrel sponge, on Conch Reef, Florida Keys. Funct Ecol 31:2188-2198

Middelburg JJ (2015) Escape by dilution. Science 348:290

* Morel A, Ahn YH, Partensky F, Vaulot D, Claustre H (1993) Prochlorococcus and Synechococcus: a comparative study of their optical properties in relation to their size and pigmentation. J Mar Res 51:617-649

Morganti T, Coma R, Yahel G, Ribes M (2017) Trophic niche separation that facilitates co-existence of high and low microbial abundance sponges is revealed by in situ study of carbon and nitrogen fluxes. Limnol Oceanogr 62: 1963-1983

Mueller B, de Goeij JM, Vermeij MJA, Mulders Y, Van Der Ent E, Ribes M, Van Duyl FC (2014) Natural diet of coralexcavating sponges consists mainly of dissolved organic carbon (DOC). PLOS ONE 9:e90152

Pawlik JR (2011) The chemical ecology of sponges on Caribbean Reefs: natural products shape natural systems. Bioscience 61:888-898

*Pawlik JR, Loh TL, McMurray SE, Finelli CM (2013) Sponge communities on Caribbean coral reefs are structured by factors that are top-down, not bottom-up. PLOS ONE 8: e62573

Pawlik JR, McMurray SE, Erwin PE, Zea S (2015a) A review of evidence for food limitation of sponges on Caribbean reefs. Mar Ecol Prog Ser 519:265-283

Pawlik JR, McMurray SE, Erwin P, Zea S (2015b) No evidence for food limitation of Caribbean reef sponges: Reply to Slattery \& Lesser (2015). Mar Ecol Prog Ser 527: 281-284

Pawlik JR, Burkepile DE, Thurber RV (2016) A vicious circle? Altered carbon and nutrient cycling may explain the low resilience of Caribbean coral reefs. Bioscience 66: 470-476

Pile AJ (1997) Finding Reiswig's missing carbon: quantification of sponge feeding using dual-beam flow cytometry. Proc 8th Int Coral Reef Symp 2:1403-1410

Pomeroy L, Williams PJleB, Azam F, Hobbie J (2007) The microbial loop. Oceanography (Wash DC) 20:28-33

* Poppell E, Weisz J, Spicer L, Massaro A, Hill A, Hill M (2014) Sponge heterotrophic capacity and bacterial community structure in high- and low-microbial abundance sponges.

Editorial responsibility: James McClintock, Birmingham, AL, USA
Mar Ecol 35:414-424

Reiswig HM (1973) Population dynamics of three Jamaican demospongiae. Bull Mar Sci 23:191-226

Reiswig HM (1974) Water transport, respiration and energetics of three tropical marine sponges. J Exp Mar Biol Ecol 14:231-249

Reiswig HM (1981) Partial carbon and energy budgets of the bacteriosponge Verongia fistularis (Porifera: Demospongiae) in Barbados. Mar Ecol 2:273-293

* Ribes M, Coma R, Gili J (1999) Natural diet and grazing rate of the temperate sponge Dysidea avara (Demospongiae, Dendroceratida) throughout an annual cycle. Mar Ecol Prog Ser 176:179-190

Kibes M, Jiménez E, Yahel G, López-Sendino P and others (2012) Functional convergence of microbes associated with temperate marine sponges. Environ Microbiol 14: 1224-1239

Kix L, de Goeij JM, Mueller CE, Struck U and others (2016) Coral mucus fuels the sponge-loop in warm- and coldwater coral reef ecosystems. Sci Rep 6:18715

* Rix L, de Goeij JM, van Oevelen D, Struck U, Al-Horani FA, Wild C, Naumann MS (2017) Differential recycling of coral and algal dissolved organic matter via the spongeloop. Funct Ecol 31:778-789

Silveira CB, Silva-Lima AW, Francini-Filho RB, Marques JSM and others (2015) Microbial and sponge-loops modify fish production in phase-shifting coral reefs. Environ Microbiol 17:3832-3846

Slattery M, Lesser M (2015) Trophic ecology of sponges from shallow to mesophotic depths (3 to $150 \mathrm{~m}$ ): Comment on Pawlik et al. (2015). Mar Ecol Prog Ser 527:275-279

Sokal RR, Rohlf FJ (1995) Biometry: the principles and practice of statistics in biological research, 3rd edn. W. H. Freeman, New York, NY

* Tupas LM, Popp BN, Karl DM (1994) Dissolved organic carbon in oligotrophic waters: experiments on sample preservation, storage and analysis. Mar Chem 45:207-216

*Weisz JB, Lindquist N, Martens CS (2008) Do associated microbial abundances impact marine demosponge pumping rates and tissue densities? Oecologia 155:367-376

*Wild C, Huettel M, Klueter A, Kremb SG, Rasheed MYM, Jorgensen BB (2004) Coral mucus functions as an energy carrier and particle trap in the reef ecosystem. Nature 428:66-70

*Wolfrath B, Barthel D (1989) Production of faecal pellets by the marine sponge Halichondria panicea Pallas (1766). J Exp Mar Biol Ecol 129:81-94

พ Yahel G, Sharp JH, Marie D, Häse C, Genin A (2003) In situ feeding and element removal in the symbiont-bearing sponge Theonella swinhoei: Bulk DOC is the major source for carbon. Limnol Oceanogr 48:141-149

Yahel G, Marie D, Genin A (2005) InEx - a direct in situ method to measure filtration rates, nutrition, and metabolism of active suspension feeders. Limnol Oceanogr Methods 3:46-58

Zea S, Henkel TP, Pawlik JR (2014) The sponge guide: a picture guide to Caribbean sponges, 3rd edn. www. spongeguide.org

Zubkov MV, Sleigh MA, Tarran GA, Burkill PH, Leakey RJG (1998) Picoplanktonic community structure on an Atlantic transect from $50^{\circ} \mathrm{N}$ to $50^{\circ} \mathrm{S}$. Deep Sea Res I 45 : 1339-1355

Submitted: September 11, 2017; Accepted: December 20, 2017 Proofs received from author(s): January 31, 2018 